\title{
Biodegradable Geomeshes for Rainsplash Erosion Control
}

\author{
Vinay-Kumar Midha*, Suresh-Kumar S, Ankush Sharma \\ Department of Textile Technology, National Institute of Technology, Jalandhar 144011, India
}

\begin{abstract}
Geomeshes can be employed to control erosion in conjunction with revegetation efforts, supplying seedbed protection from rainsplash erosion. In this study, jute and coir geomeshes were tested for erosion control performance under simulated rainfall conditions and germination using Shiwalik region soil. The performance of coir and jute geomeshes for rain splash erosion control were tested based on ASTMD-7101 using a bench-sale setup with some modifications. Germination tests were performed according to ASTM-D-7322. Rain splash erosion control tests were carried out on three different slope angles of $15^{\circ}, 30^{\circ}$ and $45^{\circ}$. Jute geomeshes resulted in the improvement of erosion control and soil stability than that of Coir. Also, the erosion control performance of geomeshes was observed to be influenced by the angle of soil slope. The objective of this study is to assess the performance capacities of biodegradable geomeshes that are commonly used for slope erosion control and vegetation establishment.
\end{abstract}

Keywords: Shiwalik Ranges; Rainsplash Erosion Test; Germination Test; Geosynthetics

\section{Introduction}

Rainsplash erosion, involves three distinct actions - soil detachment, movement and deposition. This normally leaves to the loss of soil structure and other organic matter in the soil, along with other devastating problems like landslides, floods, and desertification [1-3]. The greater the intensity and duration of rainstorm, higher is the erosion potential. The impact of raindrops on the soil surface can break down soil aggregates and disperse the aggregate material. Lighter aggregate materials such as very fine sand, silt, clay and organic matter are easily removed by the raindrop splash and runoff water. Soil management systems or bio-engineering techniques (utilization of vegetation) with geomeshes can be used to control soil erosion [4].

Geomeshes include a variety of temporary or permanently installed manufactured products designed to control erosion and enhance vegetation establishment and survivability, particularly on slopes. For applications where natural vegetation alone will provide sufficient permanent erosion protection, temporary products such as geomeshes made of biodegradable natural materials (e.g., jute and coir fiber) can be used. These products are often used on disturbed areas on steep slopes, in areas with highly erosive soils. The products function by protecting the ground surface from

${ }^{*}$ Corresponding author.

Email address: midhav@rediffmail.com (Vinay-Kumar Midha). 
the impact of raindrops and stabilize the surface until vegetation can be established as well as better control of water flow velocity [5-9]. Geomeshes also promote the growth of vegetation by helping to keep seeds in place, and by maintaining a consistent temperature and moisture content in the soil.

In this paper, coir and jute geomeshes have been studied for soil erosion control performance using lower Himalayan Shiwalik (highest erosion prone areas) soil at three different slope angles of $15^{\circ}, 30^{\circ}$ and $45^{\circ}$. In geomeshes, the contact of longitudinal warp and traverse weft yarn to the soil influences the water flow velocity and rainsplash erosion control.

\section{Materials and Methods}

The performance of jute and coir geomeshes of 500 and $700 \mathrm{~g} / \mathrm{m}^{2}$ mass was studied for rainsplash erosion control using soil from the lower foothills of the Himalayan/ Shiwalik ranges, which is composed of $40 \%$ sand, $40 \%$ silt and $20 \%$ clay particles. The Table 1 shows the characteristics of coir and jute geomeshes used. The North-western lower Himalayan foothills experience an average annual rain fall of $950 \mathrm{~mm} /$ year. During heavy rainy day, average rainfall of $100 \mathrm{~mm}$ occurs in a single day with 3 rain spells of 20 to 30 minutes each [10-13]. Testing conditions were maintained similar to these geographical factors which has a greater impact over the performance of geomeshes. The $E_{r}$ ratio (ratio between the average rainfall per day to the average rainfall per year) of these regions is $0.1[4]$.

Table 1: Characteristics of coir and jute geomeshes

\begin{tabular}{|c|c|c|c|c|c|c|c|c|c|c|c|}
\hline \multirow{3}{*}{ Grade } & \multirow{3}{*}{$\begin{array}{c}\text { Nominal } \\
\text { mass/unit } \\
\text { area }\left(\mathrm{g} / \mathrm{m}^{2}\right)\end{array}$} & \multirow{3}{*}{$\begin{array}{c}\% \\
\text { cover }\end{array}$} & \multirow{3}{*}{$\begin{array}{l}\text { Ends/ } \\
\text { meter }\end{array}$} & \multirow{3}{*}{$\begin{array}{l}\text { Picks/ } \\
\text { meter }\end{array}$} & \multirow{3}{*}{$\begin{array}{c}\text { Warp } \\
\text { linear } \\
\text { density } \\
\text { (Tex) }\end{array}$} & \multirow{3}{*}{$\begin{array}{c}\text { Weft } \\
\text { linear } \\
\text { density } \\
\text { (Tex) }\end{array}$} & \multirow{3}{*}{$\begin{array}{c}\text { Mesh } \\
\text { opening } \\
\text { size } \\
(\mathrm{mm} \times \mathrm{mm})\end{array}$} & \multicolumn{4}{|c|}{ Flexural Rigidity $(\mu \mathrm{Nm})$} \\
\hline & & & & & & & & \multicolumn{2}{|c|}{ Dry } & \multicolumn{2}{|c|}{ Wet } \\
\hline & & & & & & & & warp & weft & warp & weft \\
\hline Coir & 500 & 21 & 52 & 40 & 5895 & 4646 & $19 \times 21$ & 6388 & 1646 & 2025 & 498 \\
\hline geomesh & 700 & 33 & 58 & 46 & 4942 & 4942 & $17 \times 19$ & 7979 & 3694 & 2500 & 1114 \\
\hline Jute & 500 & 23 & 52 & 48 & 3696 & 4623 & $19 \times 21$ & 861 & 668 & 189 & 72 \\
\hline geomesh & 700 & 25 & 52 & 55 & 4049 & 4827 & $19 \times 15$ & 972 & 1089 & 227 & 292 \\
\hline
\end{tabular}

Note: Tex is used to represent the linear density of yarns and is defined as the mass of 1000 meters of yarn in grams

The performance of coir and jute geomeshes were tested in terms of rainsplash erosion control performance and germination test. The rainsplash erosion control was tested based on ASTM D 7101 using a bench-scale setup with some modifications (Fig. 1(a)) [14]. Since geomeshes have open structures with mesh opening size of $17-21 \mathrm{~mm}$, the test core of $20 \mathrm{~cm}$ diameter used in ASTM D7101 were substituted by a test tray of $75 \mathrm{~cm} \times 50 \mathrm{~cm} \times 25 \mathrm{~cm}$ [15]. Shower type rainfall simulator for heavy rainfall of $100 \mathrm{~mm} / \mathrm{hr}$ was used for simulating rainfall conditions in the laboratory.

The test trays were filled with $2 \mathrm{~cm}$ of sand at the bottom and with $20 \mathrm{~cm}$ of soil to be tested (Shiwalik soil) at the topand allowed to settle for 120 days [8]. Testing was carried out at three different slope angles of $15^{\circ}, 30^{\circ}$ and $45^{\circ}$, so the settled test trays were placed in the required angle of slope and covered with and without geomesh. Rainsplash based on the geographical conditions 

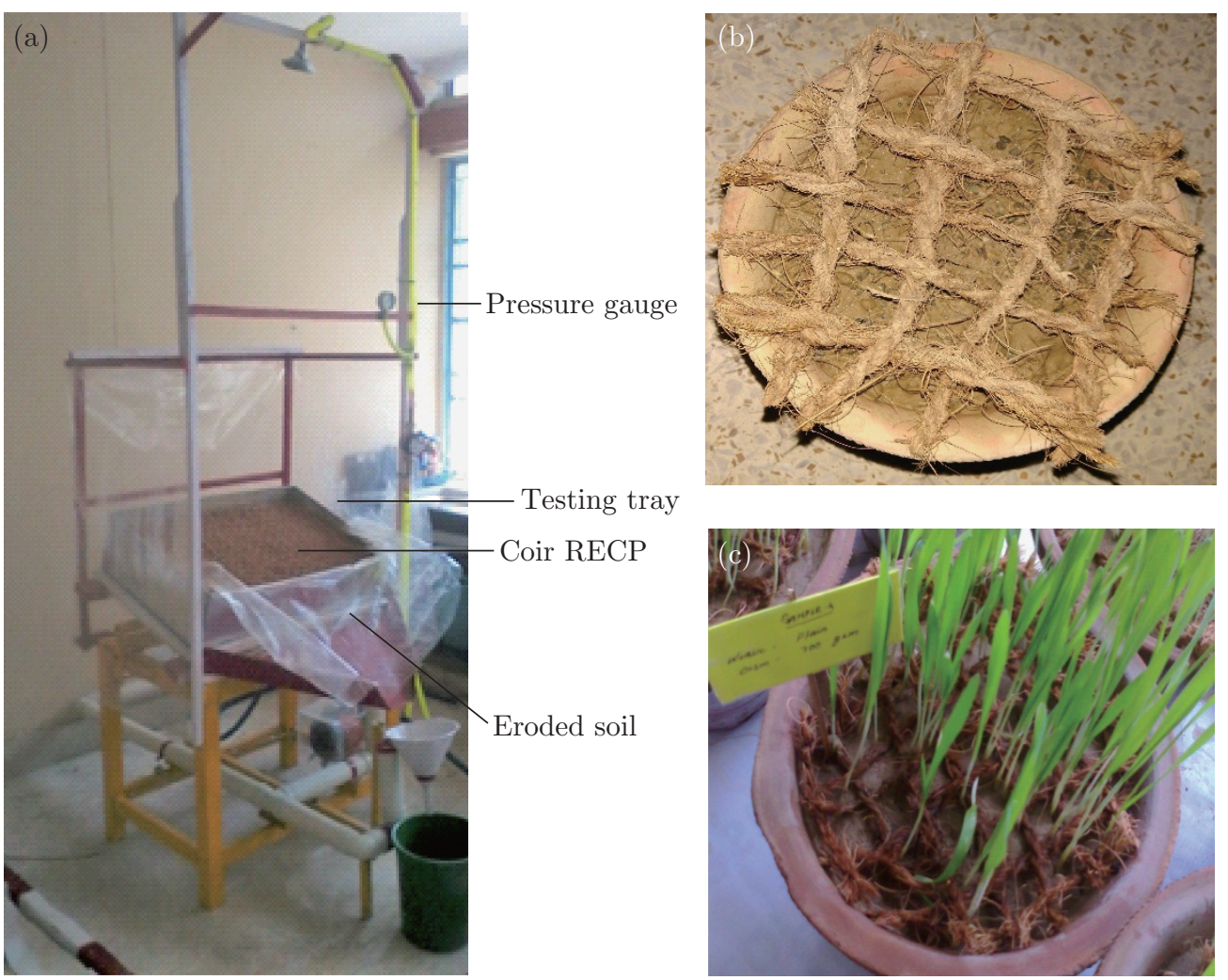

Fig. 1: Performance tests for geomeshes; (a) Rainsplash erosion control test, (b) Germination test $1^{\text {st }}$ day, (c) Germination test $21^{\text {st }}$ day

(100 mm/hr rainfall intensity) was simulated on the trays, and the eroded soil was collected for 2 minutes and weighed. The percentage difference of eroded soil from the trays with geomesh and without geomesh was calculated to evaluate the erosion control performance of geomesh using Eq. (1)

$$
\text { Erosion conrol }=\frac{\left(E_{i}-E_{w}\right)}{E_{1}} \times 100
$$

where, $E_{i}$ is weight of soil eroded without geomesh, $E_{w}$ is weight of soil eroded with geomesh.

Germination test of geomesh was carried out using earthen pots filled with soil, and sown with fixed number of wheat seeds (90 seeds/pot) according to ASTM D 7322 (Fig. 1(b)). The pots were covered with geomesh at surface of the soil and 1 pot was left uncovered for the control test. The test pots were kept at uniform temperature and lighting, and watered until the $21^{\text {st }}$ day. At the end of the $21^{\text {st }}$ day, percentage of vegetation in each pot was calculated using Eq. (2) with reference to the number of plants germinated in the control test pot [16-19].

$$
\% \text { of vegetation }=\left(\frac{\text { Number of plants germinated in the pot with geomesh }}{\text { Number of plants germinated in the pot without geomesh }}\right) \times 100
$$

Other important factors that affect the soil stability and germination of plants are the number and length of roots; so total rooting was also calculated at the end of $21^{\text {st }}$ day. Primary roots in wheat plants germinate in 10 days and secondary roots start appearing after 20 days [9]. After 21 days, the average primary root length and average number of roots/plant were measured in 
each pot by harvesting 10 plants randomly. Total rooting after 21 days was calculated using Eq. (3) $[8]$.

$$
\text { Total rooting }(\mathrm{cm})=N \times n \times L
$$

where, $N$ is the vegetation density (total number of plants germinated after 21 days), $n$ is the average number of roots/plant, and $L$ is the average root length $(\mathrm{cm})$.

Four bending length measurements were taken on each specimen; two on the face side and two on back side, and flexural rigidity was calculated using Eq. (4) [20-22].

$$
\text { Flexural rigidity }(\mu \mathrm{Nm})=\text { Fabric weigth in } \mathrm{g} / \mathrm{m}^{2} \times c^{3} \times 9.807 \times 10^{-6}
$$

where, $c$ is the bending length $(\mathrm{mm})$.

\section{Results and Discussion}

Coir and jute geomeshes have been studied for soil erosion control performance, in terms of rainsplash erosion test and germination test, using lower Himalayan Shiwalik (highest erosion prone areas) soil at three different slope angles of $15^{\circ}, 30^{\circ}$ and $45^{\circ}$.

\subsection{Rainsplash Erosion Test}

Table 2 shows the results of the rainsplash soil erosion test results. It is observed that, a significant drop in the soil erosion takes place with the use of jute and coir geomeshes. Both coir and jute geomesh are found to reduce the soil erosion. The amount of soil erosion without geomesh is $258.67 \mathrm{~g}$ as compared to $149.61 \mathrm{~g}$, when coir geomesh is used. Further, the soil erosion is found to increase as the slope increases. Figure 3 shows the soil erosion control percentage for all the jute and coir geomeshes.

\begin{tabular}{|c|c|c|c|c|c|c|}
\hline \multirow{2}{*}{ Geomeshes } & \multirow{2}{*}{$\operatorname{Mass}\left(\mathrm{g} / \mathrm{m}^{2}\right)$} & \multicolumn{3}{|c|}{ Eroded soil per min (g) } & \multirow{2}{*}{$\begin{array}{l}\text { Percentage of vegetation } \\
\text { at } 21^{\text {st }} \text { day }(\%)\end{array}$} & \multirow{2}{*}{$\begin{array}{l}\text { Total primary } \\
\text { rooting length }(\mathrm{cm})\end{array}$} \\
\hline & & $15^{\circ}$ & $30^{\circ}$ & $45^{\circ}$ & & \\
\hline \multicolumn{2}{|c|}{ Without geomesh } & 35.83 & 143 & 258.67 & - & - \\
\hline \multirow[t]{2}{*}{ Coir } & 500 & 14.66 & 74.96 & 149.61 & 81.8 & 4320 \\
\hline & 700 & 14.28 & 72.84 & 147.26 & 80.7 & 4437 \\
\hline \multirow[t]{2}{*}{ Jute } & 500 & 14.3 & 81 & 124.33 & 98.7 & 5108 \\
\hline & 700 & 8.0 & 71.33 & 107.67 & 96.1 & 5530 \\
\hline
\end{tabular}

Table 2: Rainsplash erosion and germination performance of coir and jute geomeshes

Among geomeshes of different masses, it was observed that $700 \mathrm{~g} / \mathrm{m}^{2}$ jute and coir geomeshes show higher erosion control in most of the slopes. This is due to the higher yarn density (ends or warp yarns per meter, and picks or weft yarns per meter) and higher percentage cover of $700 \mathrm{~g} / \mathrm{m}^{2}$ geomesh in comparison to the geomesh of $500 \mathrm{~g} / \mathrm{m}^{2}$ mass per unit area. Higher yarn density leads to higher number of interlacements per unit area and influences the stability of the structure. 
At higher interlacements per unit area, yarn offers higher restrictions to disorientation even at the higher velocity of water flow at steeper angles (Fig. 2). Further the higher percentage cover of the $700 \mathrm{~g} / \mathrm{m}^{2}$ geomesh reduces the direct exposure of soil to the rainfall and provides better stability to the soil. Higher percentage cover also reduces the impact of high rainfall intensity on soil which further results in less runoff erosion.

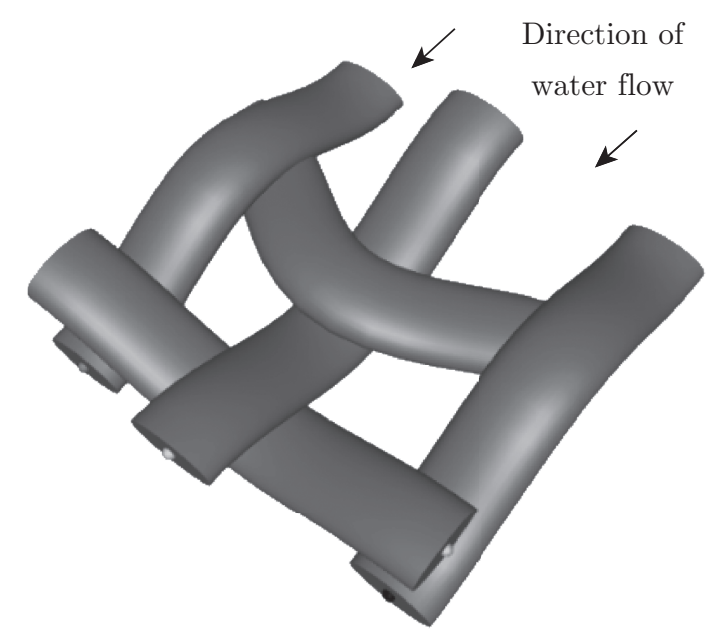

(a)

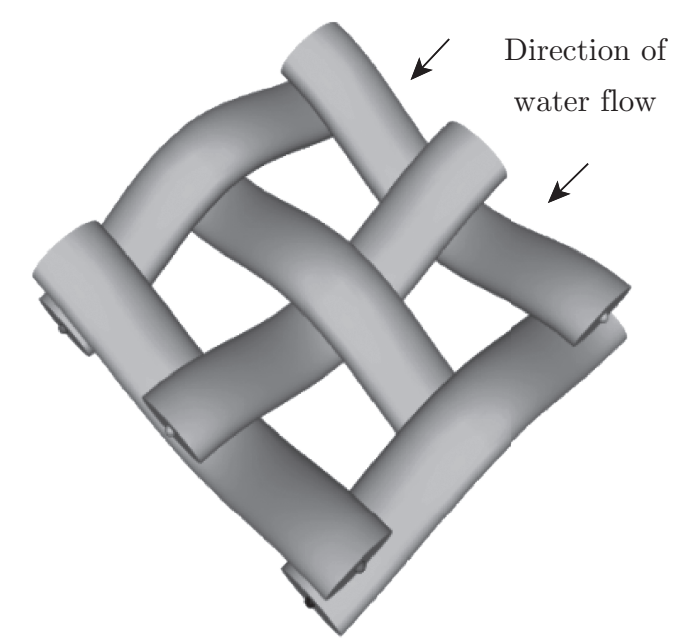

(b)

Fig. 2: Influence of ends and picks density on erosion control; (a) Geomesh with less yarn density, (b) Geomesh with high yarn density

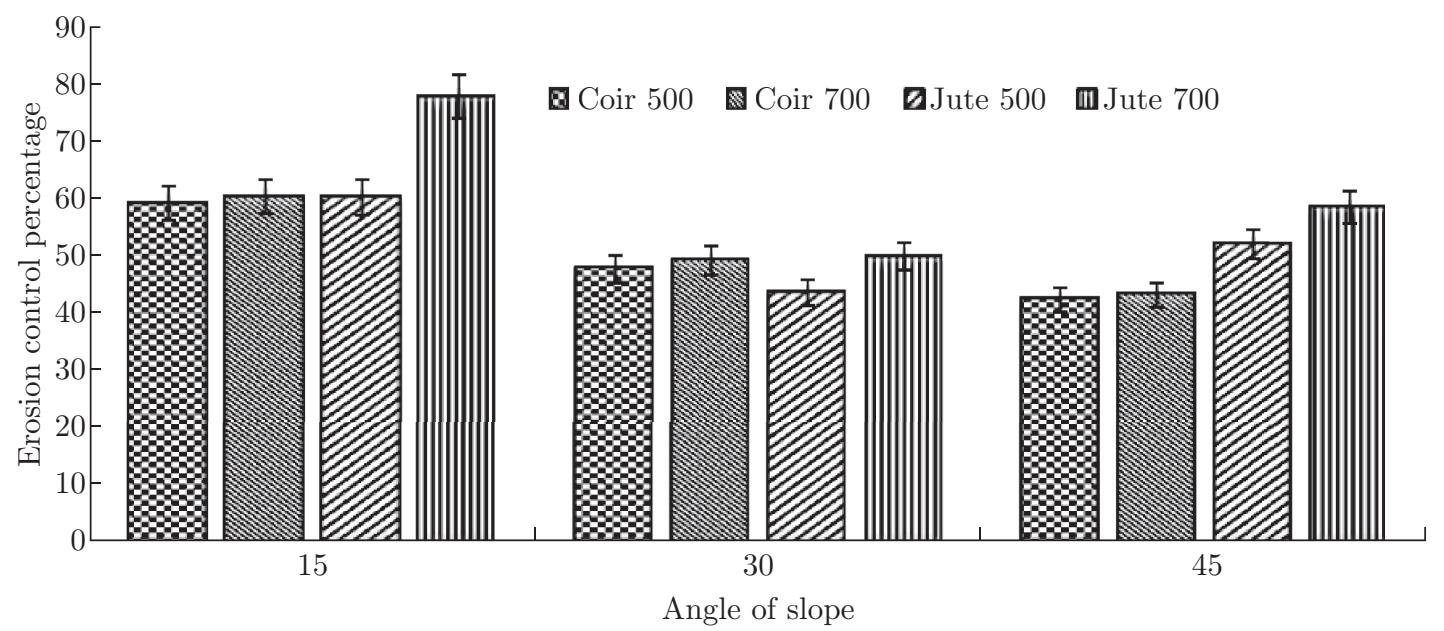

Fig. 3: Soil erosion control percentage for coir and jute geomeshes at different soil slopes

Among the jute and coir geomeshes it was observed that the jute geomesh showed better rainsplash erosion control at all angle of slopes.During rainfall and soil erosion, the soil surface develops contours (channel or path of water flow in the soil) and the contact with the geomesh gets reduced. The depth and number of contours formed depend on various factors like angle of slope, water flow velocity, and soil characteristics. Geomesh structures with lower flexural rigidity (like jute) can follow the contours easily as compared to those with higher flexural rigidity (like coir). Due to higher flexural rigidity, coir geomeshes do not follow the soil contours and therefore offer poor control over the soil erosion at higher slopes. 


\subsection{Germination test}

Table 2 shows the results of percentage vegetation and total primary rooting length grown after 21 days using different geomeshes. It is observed that the percentage vegetation reduces when the geomeshes are used, because of restrictions offered by the yarns of gemeshes to the germination of plants. However, it is observed that germination \% is more (upto 98.7\%), when jute geomeshes are used as compared to coir geomeshes. Jute fibres retain more amount of moisture as compared to coir fibres and therefore offere better microclimate for the growth of plants. Further, total rooting length of coir geomesh is also loweras compare to jute geomesh, due their lower percentage of vegetation. On the other hand, $500 \mathrm{~g} / \mathrm{m}^{2}$ geomeshwith higher percentage of vegetation were also results in lower total rooting length, due to the lower number of roots per plant and lower average root length. The average root length and number of roots per plant are much influenced by the water retaining capacity and air circulation in the soil [18], which depends on the geomesh's mass.

\section{Conclusion}

From the study, it is observed that geomeshes can be successfully used to control the soil erosion at different slopes. The amount of erosion is influenced by the slop of the soil. Increasing the mass and cover of the geomesh, increases the erosion control percentage but reduces the germination of plants. Among the coir and jute geomeshes, jute geomeshes perform better in erosion control and germination test as compared to coir geomeshes.

\section{References}

[1] Sutherland RA. A critical assessment of the research conducted at the hydraulics and erosion control laboratory: a focus on rolled erosion control systems applied to hill slopes. Geotext Geomembranes: 1998, 16: 87-118.

[2] Pimentel D. Soil erosion: a food and environment threat. J Environ Dev Sustain: 2006, 8: 119-137.

[3] Honnigford L. Guidelines for Installing Rolled Erosion Control Products in Slope- Channel and Shoreline Applications. ECTC (Erosion Control Technology Council), 2008, 1-5.

[4] Kothyari UC. Erosion and Sedimentation Problem in India. Exeter Symposium, UK. Erosion and Sediment Yield: Global and Regional Perspectives, 1996, 531-540.

[5] John NWM. Geotextiles. London: Blackie Academic and Professional, 1996, 178-85.

[6] Ogbobe O, Essien KS, Adebayo A. A Study of Biodegradable Geotextiles used for Erosion Control. Geosynth Int: 1988, 5(5): 545-553.

[7] Bhatia SK., Smith JL, Lake D, Walowsky. A Technical and Economic Evaluation of Geosynthetic Rolled Erosion Control Products in Highway Drainage Channels. Geosynth Int: 2002, 9(2): 125148.

[8] Midha VK, Suresh KS. Influence of Woven Structure on Coir Rolled Erosion-Control Products. Geosynth Int: 2013, 20(6): 396-407.

[9] MidhaVK, Sharma A, Suresh KS. Performance of Transesterified Jute Rolled Erosion Control Products. Geosynth Int: 2014, 21(5): 301-309.

[10] DEST (Department of Environment, Science \& Technology). State of Environment report on Himachal Pradesh, Narayan villa, Shimla, Himachal Pradesh, India, 2008, 30-37. 
[11] GED/RDSO (Geo-technical Engineering Directorate Research Design and Standards organization). Guidelines on Erosion Control and Drainage of Railway Formation. GED/RDSO, Lucknow, Uttar Pradesh, India, 2005, 8-12.

[12] SOE (State of environment-Atlas of India) Reports. Information on http://www.soeatlas.org/ Reports.aspx.

[13] Lenntech- Water Treatment Solutions, Rainfall Calculator. Information on http://www.lenntech. com/calculators/rain/rainfall-precipitation.html.

[14] ASTM D 7101. Standard Index Test Method for Determination of Unvegetated Rolled Erosion Control Product (RECP), Ability to Protect Soil from Rain Splash and Associated Runoff Under Bench-Scale Conditions. Pennsylvania: American Society for Testing and Materials. West Conshohocken.

[15] Fan JC, Wu MF. Sustaining the Global Farm, Effect of Soil Strength, Texture, Slope Steepness and Rain Fall Intensity on Interrill Erosion of Soils in Taiwan. Indiana: International Soil Conservation Organization, Purdue University, 1999, 588-593.

[16] ASTM-D-7322. Standard Test Method for Determination of Rolled Erosion Control Product (RECP). Ability to Encourage Seed Germination and Plant Growth Under Bench-Scale Conditions. Pennsylvania: American Society for Testing and Materials, West Conshohocken.

[17] Allen SR. Evaluation and standardization of rolled erosion control products. Geotext Geomembranes; 1996, 14: 207-221.

[18] Li MH, Khanna S. Aging of rolled erosion control products for channel erosion control. Geosynth Int: 2008, 15: 224-231.

[19] Blum A. Plant Breeding for water- limited Environments. New York: Springer Publishing, 2010, $112-44$

[20] Angappan P, Gopalakrishnan R. Textile Testing. Komarapalyam: SSMITT Staff and Students Co-operative Stores Ltd., 2002, 281-284.

[21] Booth JE. Principle of textile testing. New Delhi: CBS, 1996, 353-380.

[22] Saville BP. Physical Testing of Textiles. Cambridge: Woodhead Publishers, 2002, 256-260. 